\title{
Penguat Jembatan sebagai Pengganda Daya Penguat
}

\author{
Budihardja Murtianta \\ Program Studi Teknik Elektro, \\ Fakultas Teknik Elektronika dan Komputer, \\ Universitas Kristen Satya Wacana, Salatiga \\ budihardja@yahoo.com
}

\section{Ringkasan}

Penguat audio mempunyai daya maksimum tertentu karena besar tegangan atau arus keluaran terbatas pada suatu nilai tertentu. Tegangan keluaran maksimum terbatas pada besar tegangan catu dayanya dan arus keluaran maksimum terbatas pada batas arus dari transistor daya atau penguat operasi pada penguat akhirnya. Ada 2 cara untuk memperbesar daya keluaran penguat akhir (power amplifier) audio tersebut, yaitu memperbesar tegangan keluaran (bridged modes) atau memperbesar arus keluaran (paralleled modes) penguat akhir audio. Pada tulisan ini akan dibahas tentang memperbesar daya penguat akhir audio dengan metode jembatan atau bridged modes. Prinsip Penguat Jembatan ini juga dikenal dengan Bridge-Tied Load (BTL) atau Bridged Transformerless. Penguat akhir audio yang dipergunakan adalah cepis TDA2050. Besaran yang akan dilihat dan diukur adalah bati, masukan, keluaran dan impedansi penguat jembatan dibandingkan dengan penguat biasa. Secara teoritis pada penguat jembatan tegangan keluarannya bisa ditingkatkan $2 x$, maka dayanya akan meningkat $4 x$ dengan beban yang sama. Dari hasil penelitian penguat jembatan menghasilkan daya 2,5 kali daya penguat tunggal dan impedansinya meningkat dari $0,52 \Omega$ menjadi $0,8 \Omega$.

Kata kunci: bridged modes, penguat jembatan, cepis

\section{Pendahuluan}

Pada umumnya penguat operasi dengan tegangan catu daya $\pm 15 \mathrm{~V}$ dc akan menghasilkan ayunan tegangan keluaran sebesar $25 \mathrm{Vpp}$ [1]. Jadi sekitar $5 \mathrm{~V}$ dari total tegangan catu daya $30 \mathrm{~V}$ akan hilang untuk biasing komponen-komponen dalam cepis. Untuk ayunan tegangan keluaran yang lebih tinggi diperlukan penguat akhir tegangan tinggi dan catu daya tegangan tinggi yang memerlukan biaya beberapa kali lipat dari penguat operasi tegangan lebih rendah. Untuk mengatasi masalah tersebut dapat dipergunakan penguat operasi diferensial yang mempunyai dua keluaran dengan masing-masing keluaran saling berbeda fase $180^{\circ}$ atau berlawanan fase. 


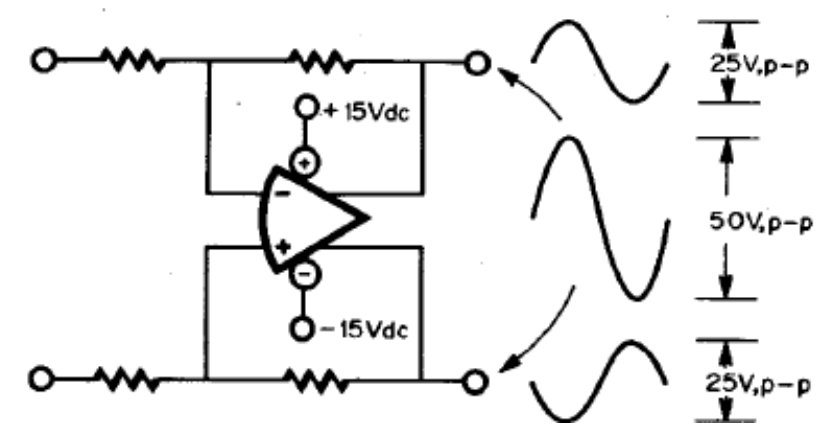

Gambar 1. Dua keluaran dari keluaran penguat operasi diferensial

Pada Gambar 1 tampak ayunan tegangan keluaran jauh di atas tegangan total catu daya. Ayunan tegangan $50 \mathrm{Vpp}$ dapat dihasilkan oleh keluaran penguat diferensial hanya dari tegangan $30 \mathrm{~V}$ dari catu daya $\pm 15 \mathrm{~V}$ dc. Pada saat bersamaan kedua keluaran tersebut dapat menghasilkan ayunan tegangan $25 \mathrm{Vpp}$ saling berlawanan fase sehingga ayunan tegangan total antara kedua keluaran adalah $50 \mathrm{Vpp}$.

Dengan menggunakan 2 buah cepis penguat operasi dapat dirangkai membentuk konfigurasi Penguat Jembatan seperti pada Gambar 2. Masukan audio dihubungkan dengan masukan tak membalik pada penguat operasi A1 dan masukan membalik pada penguat operasi A2 sehingga pada kedua keluaran penguat akan dihasilkan ayunan tegangan yang saling berlawana fase sehingga tegangan antara kedua keluaran tersebut dihasilkan ayunan sebesar 2x ayunan tegangan keluaran penguat operasi tunggal.

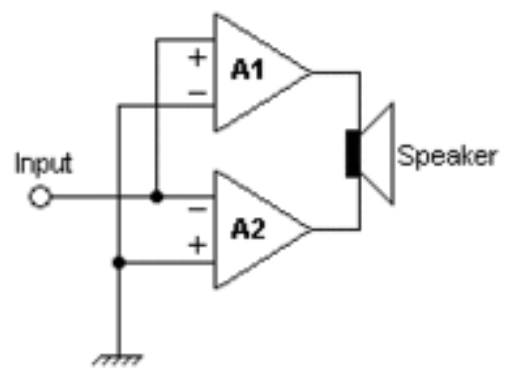

Gambar 2. Konfigurasi Penguat Jembatan

\section{Dasar Teori}

\subsection{Penguat Operasi}

Prinsip dasar yang digunakan dalam melakukan analisis yang disederhanakan untuk rangkaian umpan balik penguat operasi ada dua:

1. Apabila umpan balik negatip diberikan pada sebuah penguat operasi ideal, tegangan masukan diferensial adalah sama dengan nol.

2. Tidak ada arus yang mengalir pada kedua terminal masukan dari sebuah penguat operasi ideal. 

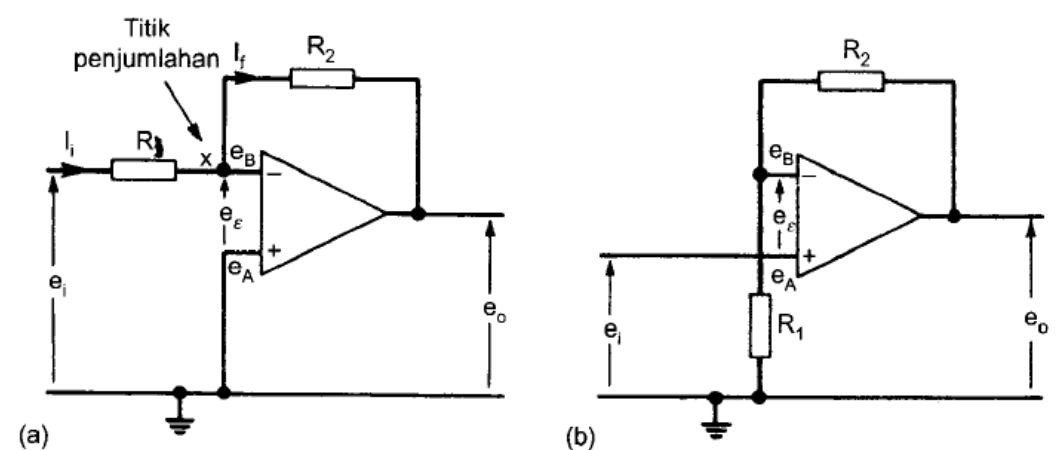

Gambar 3. Dua buah rangkaian umpan balik dasar

Dari pernyataan 1 tersebut berarti titik x pada Gambar 3a sama dengan titik bumi (ground) yang berarti impedansi masukan penguat operasi membalik ditentukan oleh besarnya hambatan $R_{2}$. Pada Gambar $3 b$ dari pernyataan 2 berarti impedansi masukan penguat operasi tak membalik adalah besar dan idealnya tak berhingga.

Bati tegangan untuk penguat operasi membalik [2]:

$$
A v=\frac{e o}{e i}=-R 2 / R 1
$$

Bati tegangan untuk penguat operasi tak mebalik:

$$
A v=\frac{e o}{e i}=1+R 2 / R 1
$$

Impedansi keluaran penguat operasi besarnya tergantung konfigurasi penguat operasi yang terdiri dari umpan balik seri dan umpan balik paralel seperti pada Gambar 4a dan Gambar 4b.

untuk tegangan seri:

$$
\beta=R 1 /(R 1+R 2)
$$

untuk tegangan parallel:

$$
\beta=R 1 /(R 1+R 2+R s)
$$

Impedansi keluaran:

$$
Z c l=\frac{Z o}{1+\beta A o l}
$$

Di mana: $\quad Z o=$ impedansi open loop (umumnya $=50 \Omega$ )

$$
\text { Aol = bati open loop }
$$

Hubungan antara tegangan keluaran penguat dengan beban $\mathrm{Z} l$ dan tegangan sumber penguat dengan hambatan keluaran penguat $Z o$ adalah sebagai berikut:

$$
E o=\frac{Z l}{Z o+Z l} V o
$$

Di mana $V o$ dalam hal ini adalah $=-A$ oc. Ee 


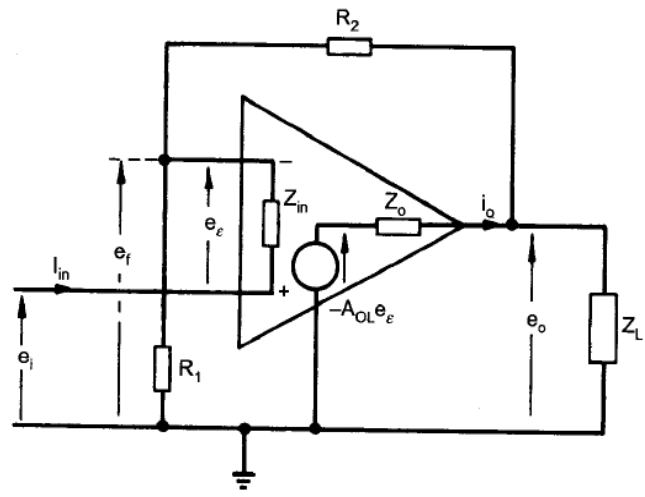

Gambar 4a. Umpan balik tegangan seri

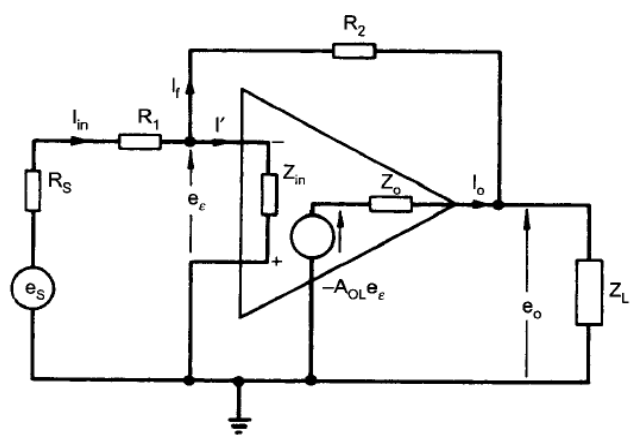

Gambar 4b. Umpan balik tegangan paralel

\subsection{Perpindahan Daya Maksimum}

Perpindahan daya yang dimaksud adalah perpindahan daya dari sumber daya atau penghasil daya menuju ke beban. Pada Gambar 5 ditunjukkan sumber daya dengan tegangan $\mathrm{Vg}$ dan impedansi dalam $\mathrm{Zg}$ disalurkan menuju beban dengan impedansi $\mathrm{Zl}$. Perlu diketahui impedansi dalam sumber $\mathrm{Zg}$ terdiri dari resistansi $\mathrm{Rg}$ dan reaktansi $\mathrm{Xg}$ sedang impedansi beban $\mathrm{Zl}$ terdiri dari resistansi Rl dan reaktansi Xl.

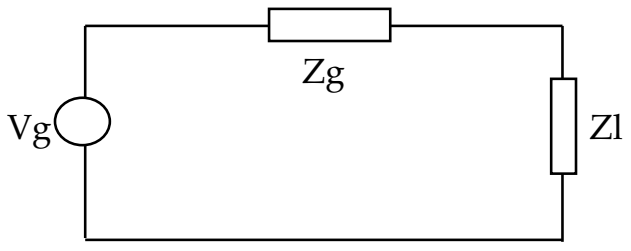

Gambar 5. Untai setara sumber tegangan dan beban

Adapun syarat agar terjadi pemindahan daya maksimum yaitu [3]:

$$
R l=R g \text { dan } X l=-X g
$$

\subsection{Keunggulan Penguat Jembatan}

Keunggulan penguat jembatan adalah ayunan tegangan keluaran lebih besar dua kali dengan menggunakan tegangan catu daya yang sama.

Karena dua penguat digunakan dalam polaritas yang berlawanan, menggunakan catu daya yang sama, tidak perlu untuk menggunakan kapasitor pemblokiran DC antara penguat dan beban. Ini menghemat biaya dan ruang, dan tidak ada pengurangan daya pada frekuensi rendah karena pengaruh kapasitor [4].

\section{Perancangan Untai Penguat Jembatan}

Penguat operasi yang dipergunakan adalah TDA2050 yang merupakan penguat daya [5]. Berdasarkan komponen yang dipasang seperti Gambar 6, maka akan diperoleh:

a. Penguat operasi tak membalik pada sisi atas

Bati tegangan $=33,35$ sesuai Persamaan $(2)$

Hambatan masukan $=22 \mathrm{~K}$

Aol menurut data sheet $=80 \mathrm{~dB}$ 
Hambatan keluaran $=0,17 \Omega$ sesuai Persamaan (5)

b. Penguat operasi membalik pada sisi bawah

Bati tegangan $=-1$ sesuai Persamaan (1)

Hambatan masukan $=680 \Omega$

Dalam hal ini masukan sumber audio tidak secara langsung dimasukkan ke masukan membalik penguat operasi sisi bawah karena akan terbeban mengingat hambatan masukan membalik relatip kecil. Sumber audio dimasukkan ke masukan tak membalik penguat operasi di mana impedansi masukannya tinggi sehingga tidak membebani tegangan sumber tersebut. Sedang keluaran penguat operasi sisi atas yang dihubungkan ke masukan tak membalik penguat operasi sisi bawah dan tidak akan terbebani mengingat impedansi keluaran sangat kecil dibanding impedansi masukan. Bati penguat operasi membalik sisi bawah adalah 1 dan berfungsi sebagai pembalik fase aja sehingga keluaran penguat operasi atas dan bawah akan berlawanan fasenya.

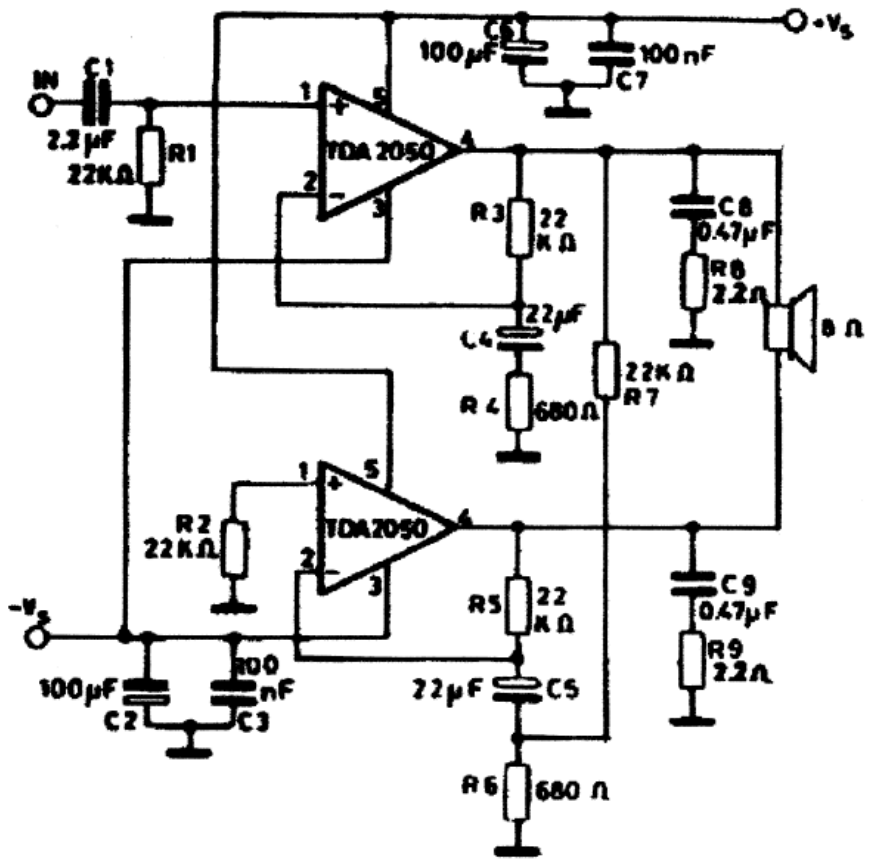

Gambar 6. Untai Penguat Jembatan

\section{Hasil Pengukuran}

Untuk kepentingan pengukuran ini penguat audio diberi pelaif untuk mengatur bati antara sinyal masukan dan keluaran, sehingga besarnya tegangan keluaran dapat diatur. Besar tegangan isyarat masukan adalah $200 \mathrm{mVp}$. Frekuensi isyarat audio yang dipergunakan sebagai sinyal tes adalah $1 \mathrm{kHz}$. Hasil pengukuran Gambar 7 sampai dengan Gambar 10 dilakukan dengan kondisi tegangan masukan dan bati penguat yang sama. 


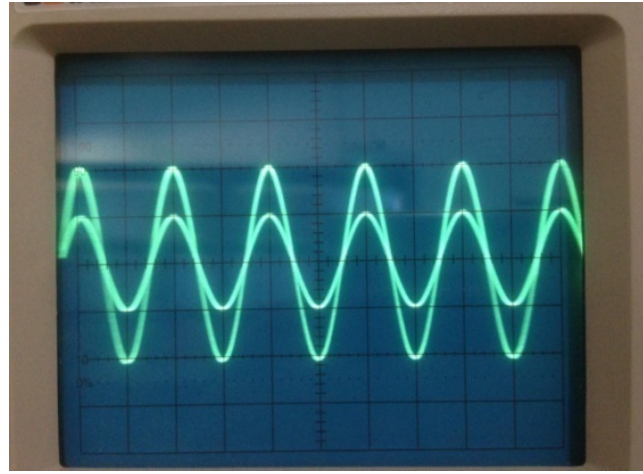

Gambar 7. Isyarat masukan dan keluaran pada penguat operasi tak membalik

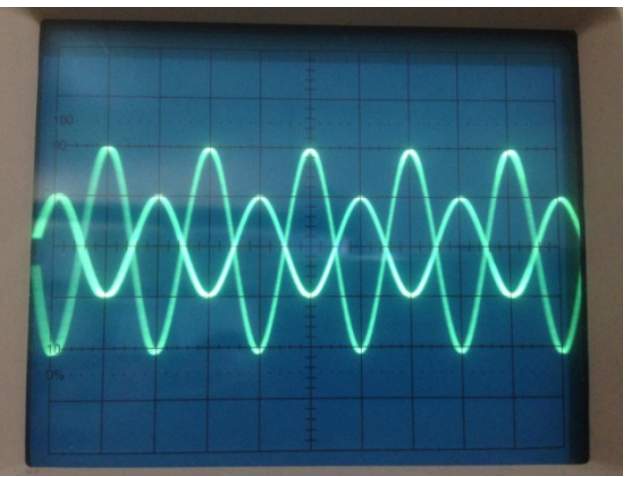

Gambar 8. Isyarat masukan dan keluaran pada penguat operasi membalik

Pada Gambar 7 tampak besar tegangan puncak isyarat keluaran penguat operasi tak membalik adalah 2 kali lebih besar dari tegangan puncak isyarat masukan dan tegangan keluaran sefase dengan tegangan masukan.

Pada Gambar 8 tampak besar tegangan puncak isyarat keluaran penguat operasi membalik adalah 2 kali lebih besar dari tegangan puncak isyarat masukan dan tegangan keluaran berlawanan fase dengan tegangan masukan.

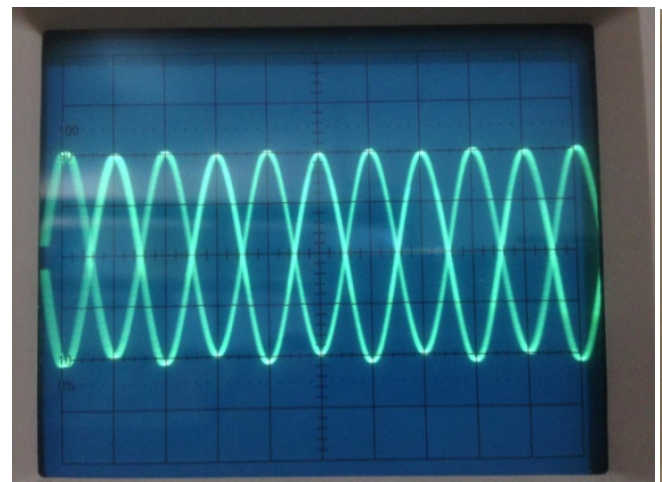

Gambar 9. Isyarat keluaran penguat operasi tak membalik dan membalik

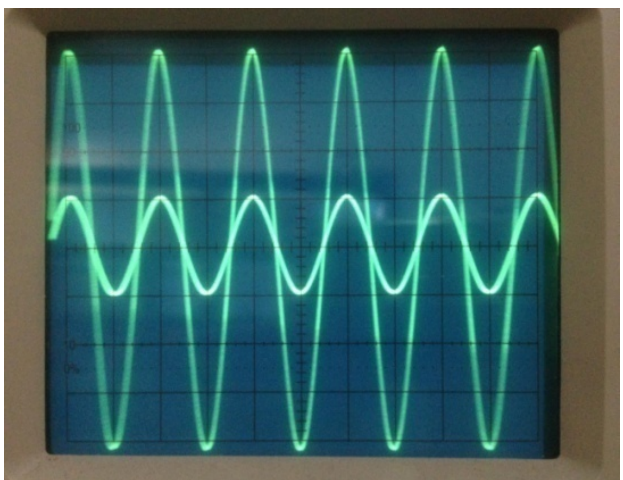

Gambar 10. Isyarat masukan dan keluaran dari penguat jembatan

Pada Gambar 9 tampak tegangan puncak keluaran penguat operasi tak membalik dan penguat operasi membalik adalah sama besar dan berlawanan fase. Tegangan puncak masukan penguat dibuat sama besar dengan sebelumnya.

Pada Gambar 10 tampak tegangan puncak keluaran penguat jembatan yaitu tegangan keluaran antara penguat operasi tak membalik dan penguat operasi membalik besarnya 4 kali lebih besar dari tegangan puncak masukan dan itu berarti 2 kali lebih besar dari tegangan puncak penguat biasa tanpa jembatan. 


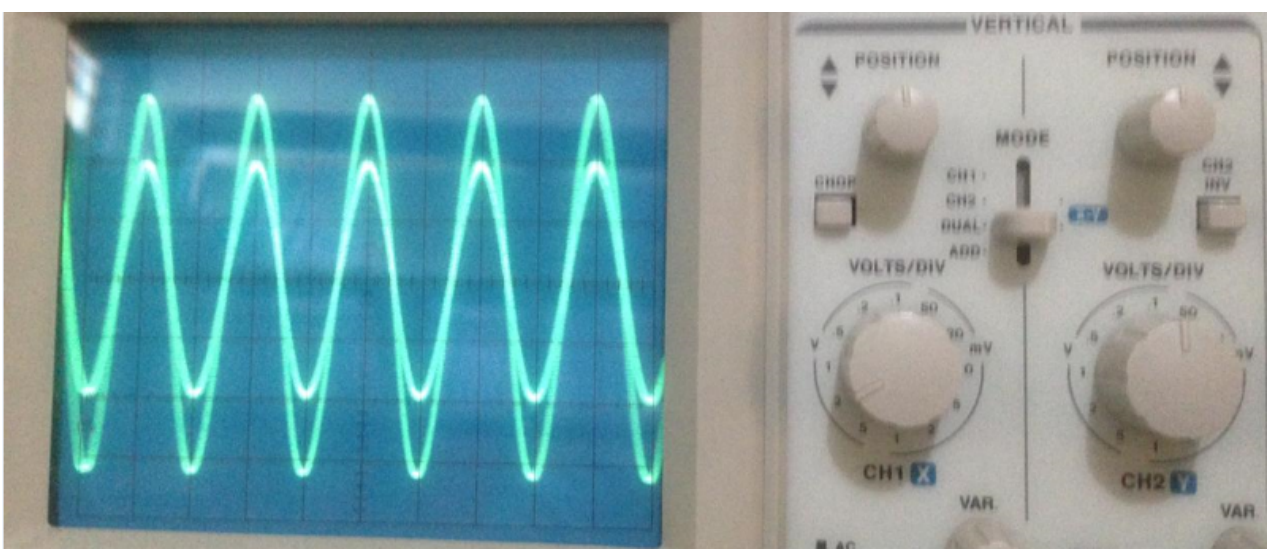

Gambar 11. Gambar masukan dan keluaran penguat tunggal dengan bati \pm 33 kali

Pada Gambar 11 tampak besarnya tegangan puncak keluaran adalah 6,6 Vp (3,3DIV x 2V/DIV) dan besarnya tegangan puncak masukan adalah $200 \mathrm{mV}$ (2DIV x 0,1V/DIV). Dari hasil tersebut diperoleh bati penguat jembatan adalah 33 kali.

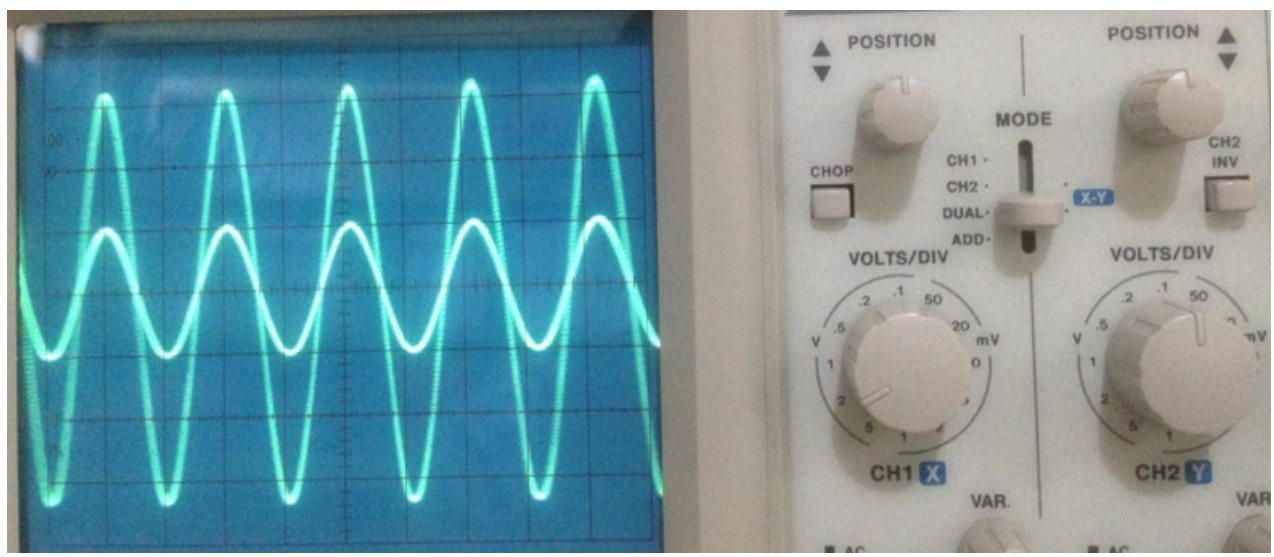

Gambar 12. Gambar masukan dan keluaran penguat jembatan dengan bati \pm 66 kali

Pada Gambar 12 tampak besarnya tegangan puncak keluaran adalah 6,6 Vp (3,3DIV x 2V/DIV) dan besarnya tegangan puncak masukan adalah $100 \mathrm{mV}$ (1DIV x 0,1V/DIV). Dari hasil tersebut diperoleh bati penguat jembatan adalah 66 kali.

Tabel 1. Tegangan keluaran penguat

\begin{tabular}{ccc}
\hline Tanpa Beban & Penguat Operasi Tunggal & Penguat Jembatan \\
\hline Vo $($ Volt $)$ & 4 & 4 \\
\hline Beban $\mathrm{R}=10 \Omega$ & Penguat Operasi Tunggal & Penguat Jembatan \\
\hline Vo $($ Volt $)$ & 3,8 & 3,7 \\
\hline
\end{tabular}

Pada Tabel 1 dapat dilihat hasil pengukuran keluaran penguat dengan menggunakan beban $10 \Omega$. Dengan menggunakan Persamaan (6) akan diperoleh besarnya hambatan keluaran penguat operasi tunggal $=0,52 \Omega$ dan hambatan keluaran penguat jembatan $=$ $0,8 \Omega$. Dengan demikian daya keluaran penguat jembatan tidak akan mencapai 4 kali daya penguat tunggal karena impedansi keluaran penguat jembatan lebih besar daripada penguat tunggal. 


\section{Kesimpulan}

Dari hasil percobaan dan pengukuran pada untai penguat jembatan ini dapat ditarik kesimpulan sebagai berikut: Penguat jembatan yang terdiri dari dua penguat tunggal mempunyai amplitudo keluaran 2 kali lipat, impedansinya dari $0,52 \Omega$ menjadi $0,8 \Omega$, bati tegangan 2 kali lipat serta daya keluarannya menjadi 2,5 kali.

\section{Daftar Pustaka}

[1] Graeme, Jerald G, "Application of Operational Amplifier", McGraw-Hill, 1973.

[2] Clayton, George \& Winder, Steve," Operational Amplifiers", Penerbit Erlangga, Jakarta 2005.

[3] Edminister, Joseph A \& Nahvi, Mahmood,"Rangkaian Listrik" Edisi ke-4, Penerbit Erlangga, 2004

[4] Self, Douglas,"Audio Power Amplifier Design Handbook", Fifth Edition, Focal Press, 2009

[5] Bartlett, Bruce (May 1, 2010). "Amplifier Power Master Class: Not All Ratings Are Similar". ProSoundWeb, https://www.prosoundweb.com/topics/education/amplifier _power_master_class_not_all_ratings_are_similar/, diunduh tanggal 5 Maret 2019 